\title{
The Effect of Aggregate Volume Ratio on the Elastic Modulus and Compressive Strength of Lightweight Concrete
}

Chung-Chia Yang

Associate Professor, Institute of Materials Engineering, National Taiwan Ocean University, Keelung, Taiwan, R.O.C.

Yung-Shin Yang

Graduate Student, Institute ofMaterials Engineering, National Taiwan Ocean University, Keelung, Taiwan, R.O.C.

Ran Huang

Professor, Department of Harbor and River Engineering, National Taiwan Ocean University, Keelung, Taiwan, R.O.C.

Follow this and additional works at: https://jmstt.ntou.edu.tw/journal

Part of the Engineering Commons

\section{Recommended Citation}

Yang, Chung-Chia; Yang, Yung-Shin; and Huang, Ran (1997) "The Effect of Aggregate Volume Ratio on the Elastic Modulus and Compressive Strength of Lightweight Concrete," Journal of Marine Science and Technology: Vol. 5: Iss.

1, Article 4.

DOI: $10.51400 / 2709-6998.2535$

Available at: https://jmstt.ntou.edu.tw/journal/vol5/iss1/4

This Research Article is brought to you for free and open access by Journal of Marine Science and Technology. It has been accepted for inclusion in Journal of Marine Science and Technology by an authorized editor of Journal of Marine Science and Technology. 
The Effect of Aggregate Volume Ratio on the Elastic Modulus and Compressive Strength of Lightweight Concrete

Acknowledgements

The financial support of National Science Council under the grants NSC 84-2211-E-019-009 is gratefully appreciated. 


\title{
THE EFFECT OF AGGREGATE VOLUME RATIO ON THE ELASTIC MODULUS AND COMPRES- SIVE STRENGTH OF LIGHTWEIGHT CONCRETE
}

\author{
Chung-Chia Yang*, Yung-Shin Yang** and Ran Huang***
}

Keywords: Water-cementratio, Lightweight aggregate, Elastic moduli, Fine aggregate, S/A ratio.

\section{ABSTRACT}

In order to investigate the effect of aggregate volume ratio (S/ A, volume of sand/ volume of total aggregate) on the elastic modulus of lightweight concrete, cylindrical specimens $(\phi 10 \times 200$ $\mathrm{mm}$ ) with different $\mathrm{S} / \mathrm{A}$ ratios and various water-cement ratios were cast and tested. Both single inclusion model and double inclusion model were applied to predict the elastic moduli of two-phase and three-phase cement-based composite materials, respectively. The elastic modulus of lightweight aggregate was obtained based on composite theory models. In this study, the aggregate volume ratio significantly affects the elastic properties of lightweight concrete. The elastic modulus and compressive strength of lightweight concrete increase as S/A ratio increases.

\section{INTRODUCTION}

A composite can be defined as a combination of at least two different materials. Usually the properties of multiphase composite have different properties of the original components. It is appropriate to consider concrete as a cement-based composite which consists of coarse aggregate embedded in a matrix of hydrated mortar.

The elastic modulus of concrete is very difficult to predict because the properties of concrete is influenced by the properties and quantities of the components. The extremely complex mechanical behavior of concrete has forced the design engineers to assume that it behaves as a homogeneous, isotropic, elastic

Paper Received January, 1997. Revised April, 1997. Accepted April, 1997. Author for Correspondence: Chung-Chia Yang.

*Associate Professor, Institute of Materials Engineering, National Taiwan Ocean University, Keelung, Taiwan, R.O.C.

**Graduate Student, Institute of Materials Engineering, National Taiwan Ocean University, Keelung, Taiwan, R.O.C.

***Professor, Department of Harbor and River Engineering, National Taiwan Ocean University, Keelung, Taiwan, R.O.C. material so that an average of elastic moduli and Poisson's ratios is taken. The overall mechanical behavior of composite materials has been extensively studied.

The overall elastic moduli of the concrete composite materials are given as a function of properties and volume fraction of the matrix and inclusion. The elastic properties of natural rock aggregate as inclusion can roughly be estimated from general information about the rock or directly measured on the bedrock itself; however, it is not as easy to obtain information about the elastic properties of artificially produced small particles such as lightweight aggregate.

By considering concrete as a two-phase material, Aitcin and Mehta [1], Baalbaki et al. [2] demonstrated that the elastic modulus of concrete is influenced by the elastic properties and volume fraction of aggregates. Hirsch [3] derived an equation to express the elastic modulus of concrete in terms of an empirical constant, and also provided some experimental results for the elastic modulus of concrete with different aggregates.

Voigt's [4] approximation yielded the upper bound and the Reuss's [5] approximation yielded the lower bound of the average elastic moduli theoretically. Hashin and Shtrikman [6] proposed variational principle to find bounds on the average elastic moduli of composite materials which were better than the Voigt and Reuss bounds. Hansen [7] developed mathematical models to predict the elastic moduli of composite materials based on the individual elastic modulus and volume fraction of the components. Mori and Tanaka [8] applied the concept of average field to analyze macroscopic properties of composite materials. The average field concept considers that inclusions are replaced by the matrix with eigenstrain distribution. In addition, the shape effect of dispersoids was introduced in Eshelby's [9] method to assess the properties of composite materials. The recent 
development of evaluating overall elastic modulus and overall clastic-plastic behavior was reviewed by Mura [10], Nemat-Nasser and Hori [11]. Yang and Huang [12] proposed a double inclusion model for approximating elastic modulus of concrete by employing Mori-Tanaka Theory and Eshelby's Method.

In this study, the elastic modulus of cement paste, mortars and lightweight concrete were obtained in the laboratory. Cement paste was considered as matrix. By considering mortar as a two-phase material, single inclusion model [13] was used to evaluate the equivalent elastic modulus of the fine aggregate. By considering lightweight concrete as a three-phase composite, the double inclusion model was used to evaluate the elastic modulus of lightweight coarse aggregate and the effect of S/A ratio on the elastic behavior of lightweight concrete.

\section{EXPERIMENTAL PROGRAM}

In this study, mortar is considered as a composite material in which sand particles are embedded in a matrix of hardened cement paste and lightweight concrete is a combination of cement paste, fine ag-gregate, and lightweight coarse aggregate. In the experimental program, lightweight concretes were made with different cement pastes as matrixes. The lightweight coarse aggregates were made of $90 \%$ fly ash and $10 \%$ portland cement (by weight). All the specimens were cast and cured in the laboratory.

\section{Cement Paste}

Cement paste specimens were made using Type I cement and water with four different watercement ratios $(w / c=0.4,0.45,0.5$, and 0.55$)$. The mix design is given in Table 1 . Cement paste cylinders $(\phi$ $100 \times 200 \mathrm{~mm}$ ) were cast and cured in water until the time of testing. At the age of 28 days, the elastic moduli and compressive strength of the specimens were measured according to ASTM Test Method for Static Modulus of Elasticity and Poisson's Ratio of Concrete in Compression (C-469-81) [14] and ASTM Test Method for Compressive Strength of Cylindrical Concrete Specimen (C-39-81) [15], respectively. All cylinders were ground and polished before testing to achieve smooth end surface. A testing machine with $100 \mathrm{KN}$ load capacity was used. The elastic moduli and compressive strength of cement paste are shown in Table 1. All test results are obtained by taking the average of more than four specimens.

\section{Mortar and Concrete}

Mortar specimens were made from Type I cement, superplasticizer, water, and natural sand with the same water-cement ratio as cement paste. In addition to the matrix (cement paste), mortars with a sand volume ratio of $60 \%$ were tested. The mix design is given in Table 2. Type I cement, superplasticizer, water, natural sand and lightweight coarse aggregate were used. Four water/binder ratios

Table 1. Mix proportions and properties of cement paste

\begin{tabular}{lcccc}
\hline Materials & P40 & P45 & P50 & P55 \\
\hline Water-cement ratio (W/C) & 0.40 & 0.45 & 0.50 & 0.55 \\
Water $\left(\mathrm{kg} / \mathrm{m}^{3}\right)$ & 1372.90 & 1283.68 & 1204.95 & 1135.50 \\
Cement $\left(\mathrm{kg} / \mathrm{m}^{3}\right)$ & 549.16 & 577.49 & 602.48 & 624.52 \\
Elastic modulus $(\mathrm{GPa})$ & 18.42 & 15.97 & 13.86 & 12.52 \\
Compressive strength $(\mathrm{MPa})$ & 41.69 & 35.45 & 30.75 & 27.36 \\
\hline
\end{tabular}

Table 2. Mix proportions and properties of mortars

\begin{tabular}{lcccc}
\hline Materials & M40 & M45 & M50 & M55 \\
\hline Water-cement ratio $(\mathrm{W} / \mathrm{C})$ & 0.40 & 0.45 & 0.50 & 0.55 \\
Water $\left(\mathrm{kg} / \mathrm{m}^{3}\right)$ & 209.77 & 225.74 & 235.49 & 244.10 \\
Cement $\left(\mathrm{kg} / \mathrm{m}^{3}\right)$ & 537.86 & 501.65 & 470.97 & 443.82 \\
Superplasticizer $\left(\mathrm{kg} / \mathrm{m}^{3}\right)$ & 5.38 & 0 & 0 & 0 \\
Fine aggregate $\left(\mathrm{kg} / \mathrm{m}^{3}\right)$ & 1565.4 & 1565.4 & 1565.4 & 1565.4 \\
*Elastic modulus $(\mathrm{GPa})$ & 27.34 & 25.92 & 24.33 & 22.85 \\
$* *$ Compressive strength $(\mathrm{MPa})$ & 38.79 & 31.03 & 28.83 & 28.68 \\
\hline
\end{tabular}

* average of four specimens

**average of seven specimens 
and different volume ratios of coarse aggregate $(\mathrm{S} /$ $\mathrm{A}=0.4,0.5,0.6$, and 0.7 ) were considered in the mix proportions. In order to prevent absorption of water by the artificial lightweight aggregate during mix procedure such that the water-cement ratio used in the mix can remain unchanged, the lightweight coarse aggregate was immersed in water for 30 minutes before mixing and then surface was dried with towels. The lightweight concrete mix design is given in Table 3. Mortar and concrete cylinders $(\phi 100 \times 200 \mathrm{~mm})$ were cast and cured. At the age of 28 days, the elastic moduli and compressive strength of the specimens were measured according to ASTM C 469-81 and ASTM C 39-81, respectively.

\section{THEORETICAL BACKGROUND}

In this study, mortar is considered as a twophase (cement paste and fine aggregate) composite materials and concrete is considered as a threephase (cement paste, fine aggregate and coarse aggregate) composite materials. The inclusions are randomly embedded in an infinite matrix. The calculation is divided into two stages. In the first stage, the equivalent elastic moduli of fine aggregate was calculated by single inclusion model for a two-phase composite. The second, double inclusion model for a three-phase composite was used to calculate the elastic moduli of lightweight coarse aggregate and concrete.

\section{Single Inclusion Model}

Yang and Huang proposed a theoretical model based on Mori-Tariaka theory and Eshelby's method in which the stress disturbance due to inhomogeneities while the applied remote stress is compressive can be simulated by the eigenstress caused by a fictitious misfit strain. The fictitious misfit strain (eigenstrain) was introduced to simulate the inhomogeneity effect. This model can provide a more accurate evaluation of average elastic relationships of cement-based materials with spherical inhomogeneities. In the pervious work, the overall average elastic moduli of cement-based composite $\bar{C}$ was given by

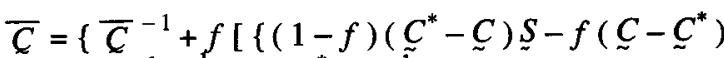

$$
\begin{aligned}
& \left.\left.+\underset{\sim}{C}\}^{-1}\right]^{-1}\left(\underset{\sim}{C}-\underline{C}^{*}\right) \underset{\sim}{C^{-1}}\right\} \text {, }
\end{aligned}
$$

where $\underset{\sim}{C}$ and $\stackrel{C}{*}^{*}$ are the elastic moduli tensor of matrix and aggregate, respectively. $f$ the volume fraction of aggregate, and $S$ is the Eshelby's tensor. The Eshelby tensor is a function of the geometry of the inclusion and Poisson's ratio of the matrix (see Appendix A).

\section{Double-Inclusion Method}

The double-inclusion method is applied to calculate the equivalent elastic modulus of lightweight coarse aggregate. The overall elastic moduli of concrete composite materials are investigated in this study by employing the theory of micromechanics.

Table 3. Mix proportions of lightweight concrete

\begin{tabular}{|c|c|c|c|c|c|c|c|}
\hline designation & $*_{w} / \mathrm{b}$ & $\begin{array}{c}\text { water } \\
\left(\mathrm{kg} / \mathrm{m}^{3}\right)\end{array}$ & $\begin{array}{l}\text { cement } \\
\left(\mathrm{kg} / \mathrm{m}^{3}\right)\end{array}$ & $\begin{array}{c}\text { SP } \\
\left(\mathrm{kg} / \mathrm{m}^{3}\right)\end{array}$ & $\begin{array}{c}\text { fine } \\
\text { aggregate } \\
\left(\mathrm{kg} / \mathrm{m}^{3}\right)\end{array}$ & $\begin{array}{c}\text { coarse } \\
\text { aggregate } \\
\left(\mathrm{kg} / \mathrm{m}^{3}\right)\end{array}$ & S/A \\
\hline C340 & & & & & 1095.8 & 291.6 & 0.7 \\
\hline C440 & 0.40 & 209.77 & 537.86 & 5.38 & 939.2 & 388.8 & 0.6 \\
\hline C540 & & & & & 782.7 & 486.0 & 0.5 \\
\hline C640 & & & & & 626.2 & 583.2 & 0.4 \\
\hline C345 & & & & & 1095.8 & 291.6 & 0.7 \\
\hline $\mathrm{C} 445$ & 0.45 & 225.74 & 501.65 & 0 & 939.2 & 388.8 & 0.6 \\
\hline C545 & & & & & 782.7 & 486.0 & 0.5 \\
\hline C645 & & & & & 626.2 & 583.2 & 0.4 \\
\hline C350 & & & & & 1095.8 & 291.6 & 0.7 \\
\hline C450 & 0.50 & 235.49 & 470.97 & 0 & 939.2 & 388.8 & 0.6 \\
\hline C550 & & & & & 782.7 & 486.0 & 0.5 \\
\hline C650 & & & & & 626.2 & 583.2 & 0.4 \\
\hline C355 & & & & & 1095.8 & 291.6 & 0.7 \\
\hline $\mathrm{C} 455$ & 0.55 & 244.10 & 443.82 & 0 & 939.2 & 388.8 & 0.6 \\
\hline C555 & & & & & 782.7 & 486.0 & 0.5 \\
\hline C655 & & & & & 626.2 & 583.2 & 0.4 \\
\hline
\end{tabular}


The inclusions are divided into two groups: fine aggregate and lightweight coarse aggregate. The overall elastic moduli of the concrete composite materials are given as a function of properties and volume fraction of the following three components: fine aggregate, coarse aggregate, and cement paste. In the pervious work, a composite material is simulated by a homogeneous material with uniform stiffness $\underset{\sim}{C}$ and distributing eigenstrains $\varepsilon_{1}^{*}$ in the domain of fine aggregate and $\varepsilon_{2}^{*}$ in the domain of coarse aggregate, respectively. The distributing eigenstrains $\varepsilon_{1}^{*}$ and $\varepsilon_{2}^{*}$ are calculated as

$$
\begin{aligned}
& \left\langle\varepsilon_{1}^{*}\right\rangle=\alpha{\underset{\sim}{0}}^{0}, \\
& \left\langle\varepsilon_{2}^{*}\right\rangle=\beta{\underset{q^{0}}{ }}^{0} .
\end{aligned}
$$

$\alpha$ and $\beta$ are shown in the Appendix B. $\sigma^{0}$ is an applied uniform remote stress. The average elastic moduli tensor of concrete composite materials, $\bar{C}$, for threephase is given by

$$
\bar{C}=\left(\underset{\sim}{C^{-1}}+f_{1} \alpha+f_{2} \beta\right)^{-1},
$$

where $f_{1}$ and $f_{2}$ are the volume fraction of fine aggregate and coarse aggregate, respectively.

\section{RESULTS AND DISCUSSIONS}

Figures 1 and 2 show the regression lines and experimental results of elastic modulus and compres-

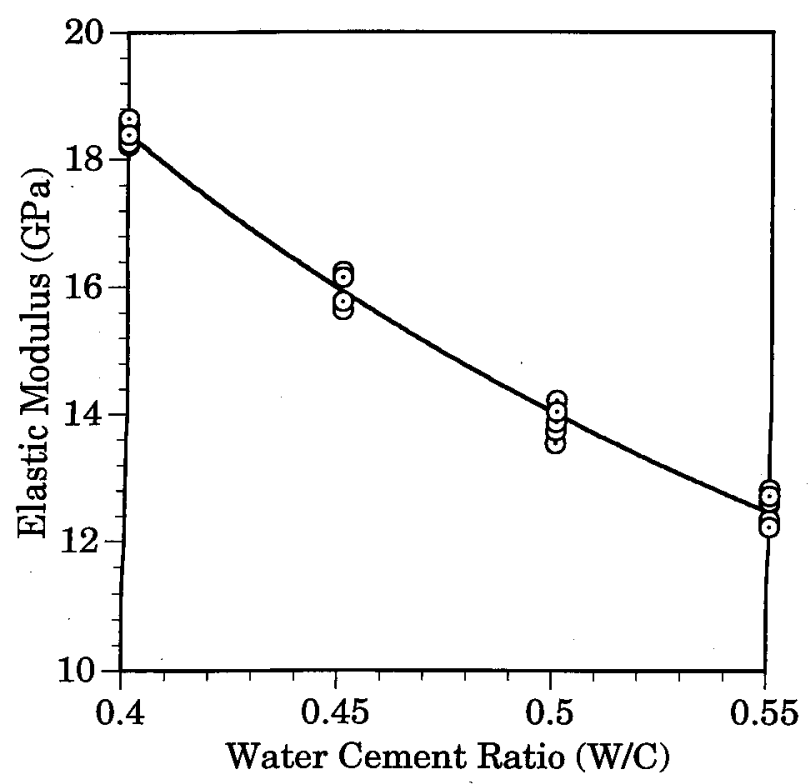

Fig. 1. Water-cement ratio vs. elastic modulus for cement paste. sive strength of cement paste with various watercement ratios, respectively. It appears that the elastic modulus of cement paste decreases as water-cement ratio increases and the compressive strength of cement paste decreases as water-cement ratio increases.

Considering mortar as a two-phase composite materials, i.e., cement paste is considered as matrix and fine aggregate is considered as inclusion. Figure 3 is the elastic moduli vs. water-cement ratio regres-

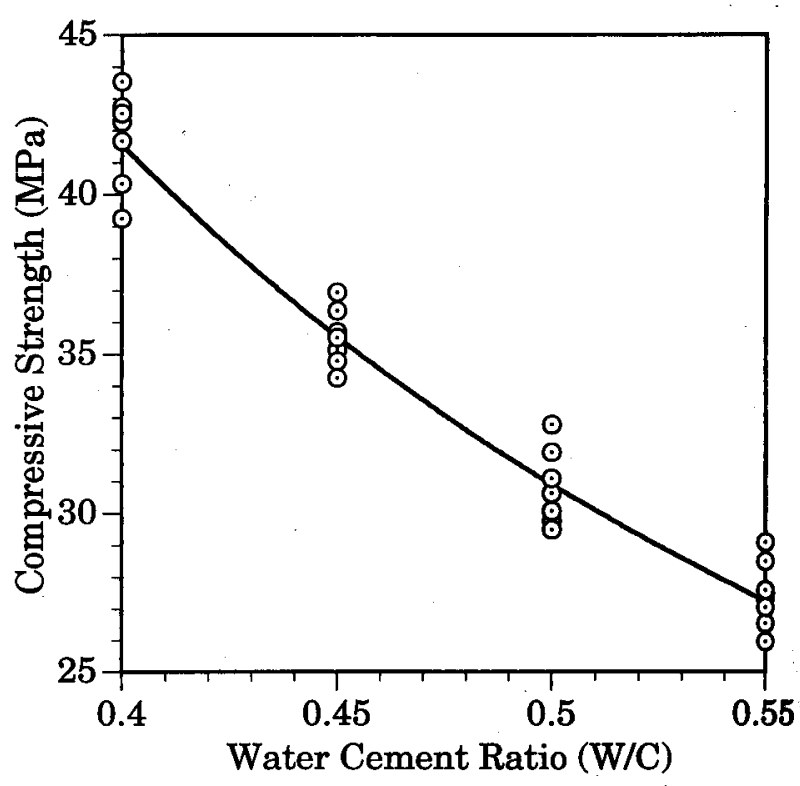

Fig. 2. Water-cement ratio vs. compressive strength for cement paste.

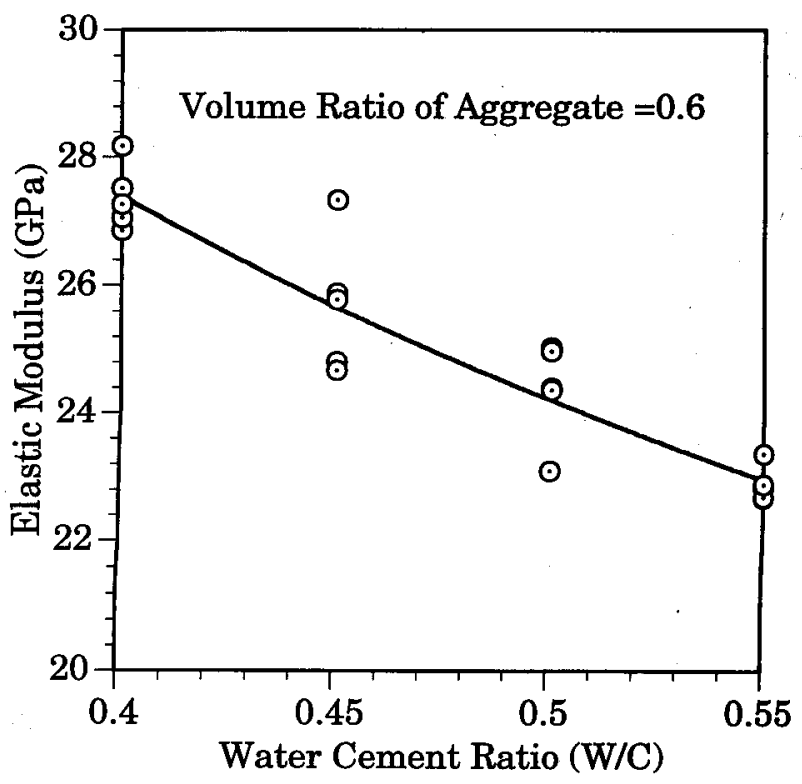

Fig. 3. Water-cement ratio vs. elastic modulus for mortar. 
sion curve and testing results for the mortar with a fine aggregate volume ratio of 0.6 . The results show that the elastic modulus of mortar decreases as watercement ratio increases.

The Poison's ratio of the cement paste and mortar was assumed to be 0.2 for the computation of the elastic modulus tensor of the matrix and the mortar according to the experimental results. Equation (1) was used to calculate the elastic modulus of the fine aggregate based on single inclusion model. Table 4 shows the elastic modulus of the fine aggregate obtained from the single inclusion model. The average elastic modulus of fine aggregate is $36.63 \mathrm{GPa}$. The regression line and experimental results for mortar are shown in Fig. 4. In this figure also shows that the compressive strength of mortar decreases as water-cement ratio increases.

A three-phase composite with spherical inclusions was considered in the theoretical approach. The elastic moduli of cement paste and fine aggregate are shown in Table 4. The elastic moduli of light-

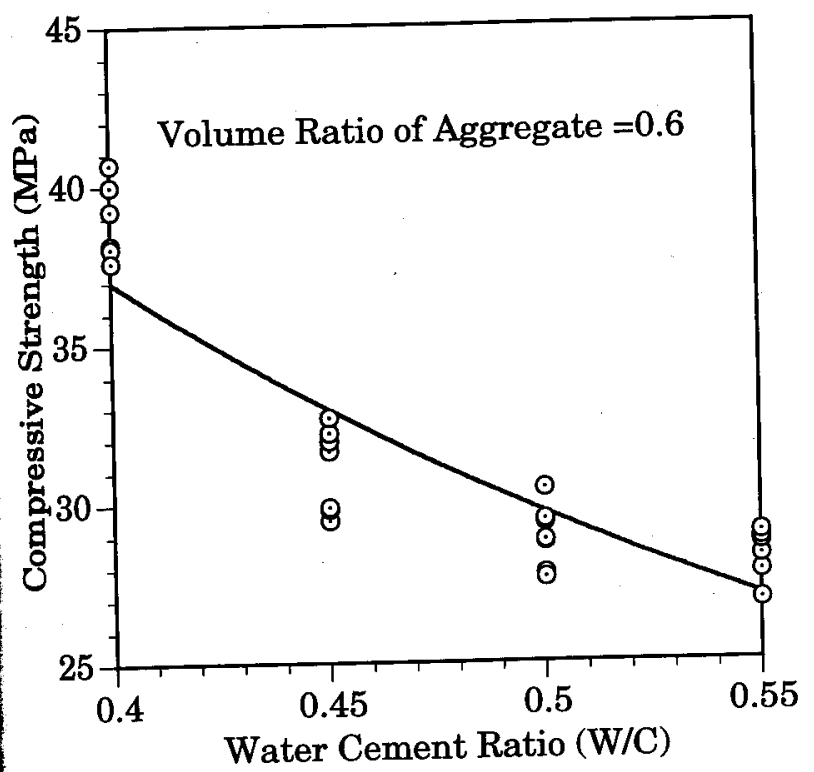

Fig. 4. Water-cement ratio vs. compressive strength for mortar.

weight concrete are experimentally obtained and listed in Table 5. The Poisson ratio of cement paste, fine aggregate, and lightweight coarse aggregate are assumed to be 0.2 . The volume ratios of fine aggregate and lightweight coarse aggregate are calculated from Table 3. The elastic modulus of lightweight coarse aggregate is computed from Eqn (4) based on the elastic moduli, Poisson ratios, and volume ratios of the components such as cement paste, fine aggregate, and lightweight concrete. Table 6 displays the elas-tic moduli of lightweight coarse aggregates. The average elastic modulus of lightweight coarse aggregate is about $5.82 \mathrm{GPa}$.

The regression lines and experimental results for lightweight concretes elastic modulus and strength are shown in Figs. 5 and 6. Figure 5 illustrates the relationships between elastic moduli of lightweight concrete and S/A ratio (fine aggregate volume/total aggregate volume) for specimens with various water-cement ratios. It appears elastic modulus of lightweight concrete increases as S/A ratio in-

Table 5. Elastic moduli of lightweight concrete, (GPa)

\begin{tabular}{cccccc}
$\begin{array}{c}\text { design- } \\
\text { ation }\end{array}$ & 1 & 2 & 3 & 4 & Average \\
\hline C340 & 19.58 & 21.63 & 18.99 & 21.15 & 20.34 \\
C440 & 18.29 & 18.81 & 18.22 & 17.81 & 18.28 \\
C540 & 17.12 & 16.77 & 15.86 & 16.20 & 16.49 \\
C640 & 14.26 & 14.57 & 14.96 & 14.48 & 14.57 \\
C345 & 18.91 & 18.41 & 18.23 & 18.91 & 18.62 \\
C445 & 16.80 & 16.79 & 17.49 & 17.64 & 17.18 \\
C545 & 15.19 & 15.01 & 14.66 & 15.77 & 15.16 \\
C645 & 14.15 & 13.71 & 13.23 & 14.23 & 13.83 \\
C350 & 18.04 & 17.45 & 18.05 & 17.40 & 17.73 \\
C450 & 15.62 & 15.42 & 15.28 & 15.61 & 15.48 \\
C550 & 13.32 & 15.03 & 14.28 & 14.19 & 14.21 \\
C650 & 13.38 & 13.25 & 12.53 & 12.84 & 13.25 \\
C355 & 17.21 & 17.01 & 17.09 & 16.56 & 16.97 \\
C455 & 14.51 & 14.25 & 14.91 & 14.81 & 14.62 \\
C555 & 13.74 & 12.85 & 12.96 & 13.46 & 13.25 \\
C655 & 10.14 & 11.21 & 13.58 & 11.80 & 11.68 \\
\hline
\end{tabular}

Table 4. Elastic modulus of cement paste, mortar, and fine aggregate, (GPa)

\begin{tabular}{|c|c|c|}
\hline $\begin{array}{c}\text { Cement paste } \\
\text { (matrix) }\end{array}$ & $\begin{array}{c}\text { Mortar } \\
\text { (two-phase composite) }\end{array}$ & $\begin{array}{c}\text { Fine aggregate } \\
\text { (inclusion) }\end{array}$ \\
\hline 18.41 & 27.34 & 36.15 \\
\hline 15.97 & 25.92 & 36.91 \\
\hline 13.85 & 24.33 & 37.22 \\
\hline 12.52 & 22.85 & 36.25 \\
\hline
\end{tabular}


Table 6. Elastic moduli of lightweight coarse aggregate

\begin{tabular}{ccccc}
\hline $\begin{array}{c}\text { Design- } \\
\text { ation }\end{array}$ & $\begin{array}{c}\text { Cement } \\
\text { paste } \\
\text { (Phase 1) }\end{array}$ & $\begin{array}{c}\text { Fine } \\
\text { aggregate } \\
\text { (Phase 2) } \\
f_{0}\end{array}$ & $\begin{array}{c}\text { Coarse } \\
\text { aggretate } \\
\text { (Phase 3) } \\
f_{2}\end{array}$ & $\begin{array}{c}\text { Elastic modulus } \\
\text { of } \\
\text { coarse aggregate } \\
\text { (GPa) }\end{array}$ \\
\hline C340 & 0.40 & 0.42 & 0.18 & 6.2 \\
C440 & 0.40 & 0.36 & 0.24 & 5.9 \\
C540 & 0.40 & 0.30 & 0.30 & 5.9 \\
C640 & 0.40 & 0.24 & 0.36 & 5.5 \\
C345 & 0.40 & 0.42 & 0.18 & 5.5 \\
C445 & 0.40 & 0.36 & 0.24 & 6.3 \\
C545 & 0.40 & 0.30 & 0.30 & 5.6 \\
C645 & 0.40 & 0.24 & 0.36 & 5.9 \\
C350 & 0.40 & 0.42 & 0.18 & 6.4 \\
C450 & 0.40 & 0.36 & 0.24 & 5.3 \\
C550 & 0.40 & 0.30 & 0.30 & 5.8 \\
C650 & 0.40 & 0.24 & 0.36 & 6.5 \\
C355 & 0.40 & 0.42 & 0.18 & 6.6 \\
C455 & 0.40 & 0.36 & 0.24 & 5.2 \\
C555 & 0.40 & 0.30 & 0.30 & 5.5 \\
C655 & 0.40 & 0.24 & 0.36 & 5.0 \\
\hline & & & & Average $=5.82$
\end{tabular}

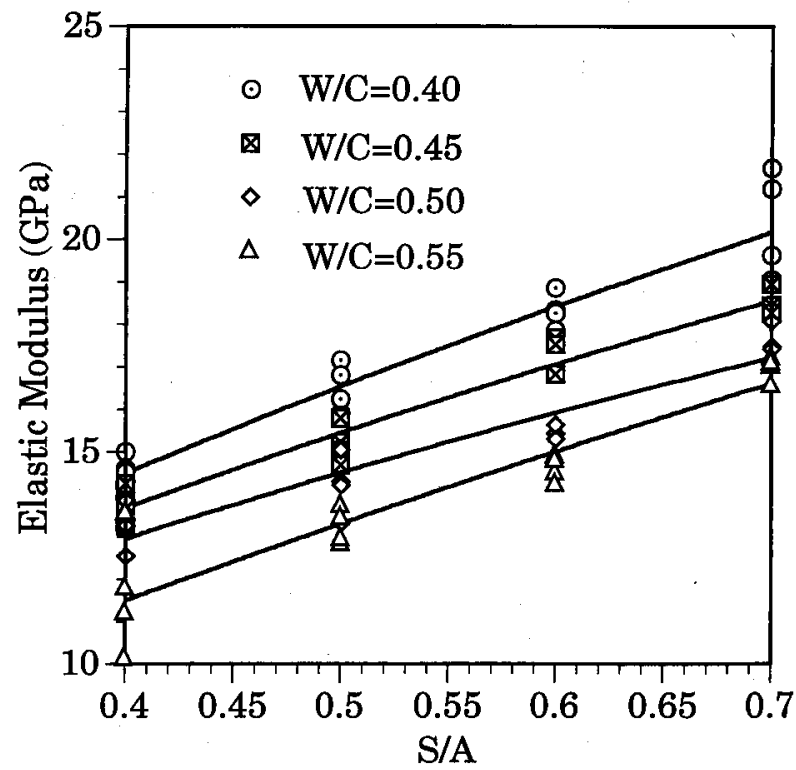

Fig. 5. Elastic modulus of lightweight concrete as a function of S/A with various $\mathrm{W} / \mathrm{C}$

creases. Figure 5 also shows that the elastic modulus of lightweight concrete decreases as water-cement ratio increases. The compressive strength vs. S/A ratio for lightweight concretes with various watercement ratios are shown in Fig. 6. The compressive strength of lightweight concrete increases as S/A ratio increases and the compressive strength of lightweight concrete decreases water-cement ratio increases as shown in Fig. 6.

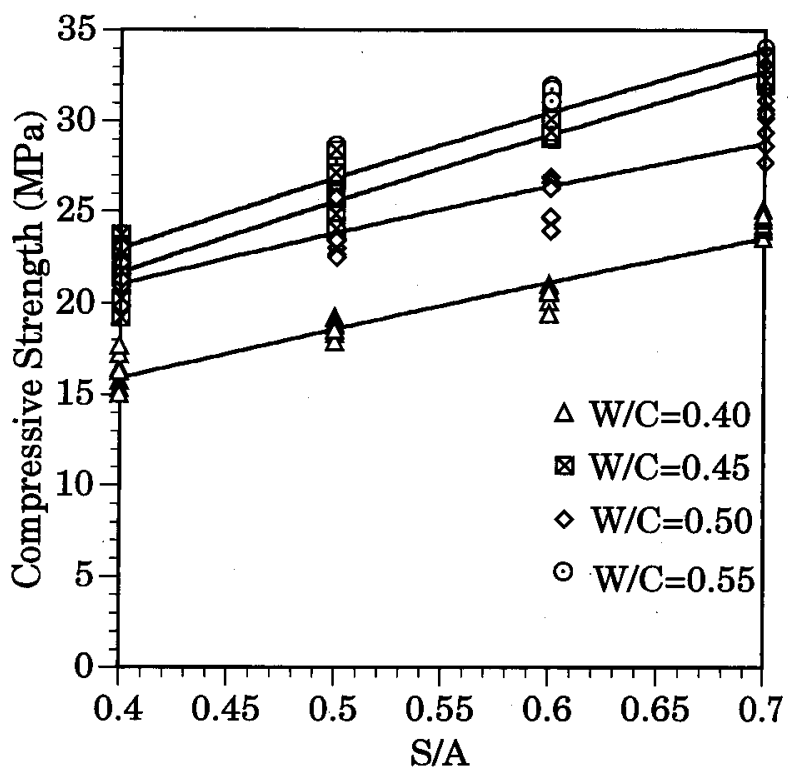

Fig. 6. compressive strength of lightweight concrete as a function of $\mathrm{S} /$ A with various W/C.

\section{CONCLUSIONS}

In this study, cement paste is considered as matrix. The elastic modulus and compressive strength of cement paste decreases with an increases in watercement ratio. The elastic modulus and compressive strength of mortar are influenced by the elastic properties and the volume ratio of the matrix (cement paste) and fine aggregate (inclusion). Based on the 
single inclusion model, the average elastic modulus of fine aggregate can be derived from the testing results. In this study, the average elastic modulus of fine aggregate is $36.63 \mathrm{GPa}$.

The volume ratio of aggregate significantly affects the elastic modulus and compressive strength of lightweight concrete. In addition, from the double inclusion model, the estimated elastic modulus of the lightweight aggregate is about $5.82 \mathrm{GPa}$.

\section{ACKNOWLEDGMENT}

The financial support of National Science Council under the grants NSC 84-2211-E-019-009 is gratefully appreciated.

\section{APPENDIX A}

The Eshelby's tensor $\underset{\sim}{S}$ for sphere inclusion is listed below [10].

$$
\begin{aligned}
& S_{1111}=S_{2222}=S_{3333}=\frac{7-5 v}{15(1-v)} . \\
& S_{1122}=S_{2233}=S_{3311}=S_{1133}=S_{2211}=S_{3322}=\frac{5 v-1}{15(1-v)} . \\
& S_{1212}=S_{2323}=S_{3131}=\frac{4-5 v}{15(1-v)} .
\end{aligned}
$$

\section{APPENDIX B}

The calculation of parameters $a$ and $b$

$$
\begin{aligned}
& A=\left[\left(1-f_{1}\right) \underset{\sim}{C}+f_{1} \underset{1}{C_{1}^{*}}\right](\underset{\sim}{S}-\underset{\sim}{I})-\underset{\sim}{C_{1}^{*}} \underset{\sim}{S} \\
& B=\left[\left(1-f_{2}\right) \underset{\sim}{C}+f_{2} \underset{\sim}{C_{2}^{*}}\right](\underset{\sim}{S}-\underset{\sim}{I})-\underset{\sim}{C_{2}^{*}} \underset{\sim}{S}
\end{aligned}
$$

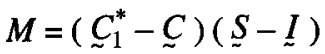

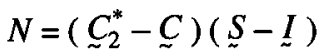

$$
\begin{aligned}
& \left\langle\varepsilon_{1}^{*}\right\rangle=-\left(I-f_{1} f_{2} A^{-1} M B^{-1} N\right)^{-1}\left[f_{2} M B^{-1}\right. \\
& \left.\left({\underset{\sim}{2}}_{2}^{*} \underset{\sim}{\tilde{C}}-\underset{\sim}{I}\right)+\left(\underset{\sim}{C_{1}^{*}} \underset{\sim}{C}-\underline{\sim}\right)\right] \widetilde{\sigma}^{0}=\alpha \underset{\sim}{\sigma^{0}}
\end{aligned}
$$

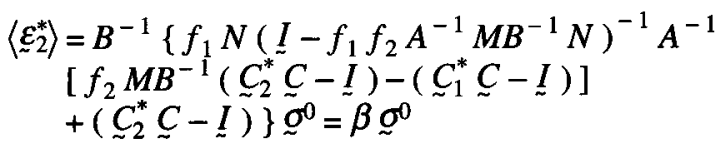

\section{REFERENCES}

1. Aitcin, P.C. and Mehta, P.K., "Effect of CoarseAggregate Characteristics on Mechanical Properties of High-Strength Concrete," ACI Mat. J., Vol. 87, pp. 103-107 (1990).

2. Baalbaki, W., Aitcin, P.C. and Ballivy, G., "On Predicting Modulus of Elasticity in High-Strength Concrete," ACI Mat. J., Vol. 89, pp. 517-520 (1992).

3. Hirsch, T.J., "Modulus of Elasticity of Concrete Affected by Elastic Moduli of Cement Paste Matrix and Aggregate," J. ACI, pp. 427-451 (1962).

4. Voigt, W., "Über die Beziehung zwischen den beiden Elastizit ät skonstanten isotroper Körper," Wied. Ann., Vol. 38, pp. 573-587 (1889).

5. Reuss, A., "Berechnung der Fliessgrenze von Mischkristallen auf Grund der Plastizitätsbedingung für Einkristalle," Z. angew. Math. Mech., Vol. 9, pp. 49-58 (1929).

6. Hashin, Z. and Shtrikman, S., "On Some Variational Principles in Anisotropic and Nonhomogeneous Elasticity," J. Mech. Phys. Solids, Vol. 10, pp. 335343 (1962).

7. Hansen, T.C.,"Strength Elasticity, and Creep as Related to the Internal Structure of Concrete," Chemistry of Cement, Proc. of the 4th Inter. Sym., Monograph , Vol. 2, 709 (1960).

8. Mori, T. and Tanaka, K., "Average Stress in Matrix and Average Energy of Materials with Misfitting Inclusions,"Acta Metall., Vol.21,pp.571-574(1973).

9. Eshelby, J.D., "The Determination of the Elastic Field of an Ellipsoidal Inclusion, and Related Problems," Proc. Roy. Soc., A241, pp. 376-396 (1957).

10. Mura, T., Micromechanics of Defects in Solids, and Edition, Martinus Nijhoff Publishers, (1987).

11. Nemat-Nasser, S. and Hori, M., Micromechanics: Overall Properties of Heterogeneous Materials, NorthHolland, (1993).

12. Yang, C.C. and Huang, R., "Double Inclusion Model for Approximate Elastic Moduli of Concrete Material," Cement and Concrete Research, Vol. 26, No. 1, pp. 83-91 (1996).

13. Yang, C.C., Huang, R., Yeih, W. and Chang, J.J., "Theoretical Approximate Elastic Moduli of Concrete Material," The Chinese J. of Mechanics, Vol. 11, pp. 47-53 (1995).

14. ASTM Test Method for Static Modulus of Elasticity and Poisson's Ratio of Concrete in Compression (C469), American Society for Testing and Materials, Philadelphia.

15. ASTM Test Method for Compressive Strength of Cylindrical Concrete Specimen (C-39), American Society for Testing and Materials, Philadelphia. 
骨材體積比對輕質混凝土彈性模數 及強度之影響

楊仲家楊永新

國立台管海洋大拲材料工程研究所

黃 然

國立台海海洋大學河海工程系所

摘 要

本研究中製作不同的細骨材含量及水灰比之 圆柱試體 $(\phi 100 \times 200 \mathrm{~mm})$ 進行宾，驗，以探討細骨材 含量對輕質混凝土彈性模数之影響並利用單相置入 模式及隻相置入模式推估兩相複合材料及三相複合 材料之彈性模数。經由試驗數據與理論式的配合, 本研究中可求得輕質骨材的平均彈性模数。研究結 果影示骨材體積比(S/A)数於輕質混凝土的彈性模 数及㻺力強度均有智著的影響, 且輕質混凝土的彈 性模數及㻺力強度將隨(S/A)之增加而增加。 